\title{
Pseudopilemia - a new subgenus of the genus Pbytoecia Dejean, 1835 (Coleoptera: Cerambycidae)
}

\author{
Pseudopilemia - новый подрод жууков-усачей рода Pbytoecia \\ Dejean, 1835 (Coleoptera: Cerambycidae)
}

\author{
D.G. Kasatkin \\ A.Г. Касаткин
}

Rostov Branch of FSI "VNIIKR”, Russia, Rostov-on-Don, 344018, 20th-line 43/16. E-mail: dorcadion@yandex.ru Ростовское отделение ФГБУ “ВНИИКР”, 20-линия 43/16, Ростов-на-Дону, 344018, Россия.

KEY WORDS: Coleoptera, Cerambycidae, Phytoecia, Pilemia, new subgenus, new synonym.

КЛЮЧЕВЫЕ СЛОВА: Coleoptera, Cerambycidae, Phytoecia, Pilemia, новый подрод, новый синоним.

ABSTRACT. The new subgenus Pseudopilemia subgen.n. of the genus Phytoecia Dejean, 1835 with the type species Saperda hirsutula Frölich, 1793 is described. Diagnostic characters of external morphology and endophallic structure of the new subgenus are given. A new synonymy is proposed: $P h$. (P.) buglanica D.Marklund et S.Marklund, $2014=$ Phytoecia $(P$. $)$ hirsutula (Frölich, 1793), syn.n.

РЕЗЮМЕ. Описан новый подрод Pseudopilemia subgen.n (типовой вид Saperda hirsutula Frölich, 1793 ) рода Phytoecia Dejean, 1835. Приведены диагностические признаки внешней морфологии и полового аппарата самца нового подрода. Предложена новая синонимия: $P h$. $(P$.) buglanica D.Marklund et S.Marklund, $2014=$ Phytoecia $(P$.) hirsutula $($ Frölich, 1793), syn.n.

\section{Introduction}

Subgenus Pilemia Fairmaire, 1864 within the genus Phytoecia Dejean, 1835 currently includes 16 species with some subspecies distributed in the Western Palearctic [Löbl, Smetana, 2010; Danilevsky, 2016, Özdikmen, Turgut, 2010, Marklund, Marklund, 2014; Szczepański, Karpiński, 2017]. The validity of some species is doubtful. Detailed study of various species of Pilemia showed that the most widespread species Phytoecia (Pilemia) hirsutu$l a$ (Frölich, 1793) and several close species distinctly differ from other species in the external morphology and the structure of endophallus, and a new separate subgenus is proposed for them. It should be noted that many of differential characters to separate these subgenera (proportions of the pronotum and eye lobes, the length and the pubescence of antennae, the structure of claws and elytral pubescence) were indicated in the Daniel's revision [1906].

\section{Material and metods}

The research is based on the examination of materials from the following private collections and institutes: National Museum of Prague (Czech Republic, Prague), Zoological Museum of Moscow University (Russia, Moscow), Natural History Museum of Vienna (Austria, Vienna), Bavarian State Collection of Zoology (Germany, Munich), Zoological Museum of Humboldt University (Germany, Berlin). The procedure of preparation cerambycids endophallus and terminology of endophallic structure were described by Kasatkin [2006].

All specimens were examined with Olympus SZ61 stereomicroscopes. The photographs were taken with Canon MP-E $65 \mathrm{~mm} / 2.8$ on bellows attached to a Canon EOS 5D Mark III camera and Canon 650D mounted on AxioLab microscope. Partially focused images were stacked using the Helicon Focus Pro v5.3.14 software.

Pseudopilemia subgen.n.

Figs 6-8, 15-16, 20, 24.

Type species: Saperda hirsutula Frölich, 1793.

DIFFERENTIAL DIAGNOSIS. The new subgenus differs from Pilemia in the following characters:

Male pygidium not emarginated at apex, rounded or straightly cut, elongated or acuminated in female; tubercles or denticles on abdominal ventrites absent; ventral lobes of eyes subequal to genal length. Inner part of claws narrow and long, not triangular (Figs 15-16). Female pygidium sharpened apically. Endophallus with very well developed basidorsal crista and other sclerits of basal phallomer; central apical sclerite slightly longer than others (Figs 20, 24); male antennae reaching elytral apex or slightly shorter, cuticle of antennomeres unicolour (without color rings); male pronotum distinctly longitudinal or square (Figs 6-8), densely covered with hairs, without red spot on disc. Elytral pubescence without contrast pattern; with quite long erect or semierect thick setae.

How to cite this article: Kasatkin D.G. 2018. Pseudopilemia - a new subgenus of the genus Phytoecia Dejean, 1835 (Coleoptera: Cerambycidae) // Russian Entomol. J. Vol.27. No.2. P.157-160. doi: 10.15298/rusentj.27.2.06 

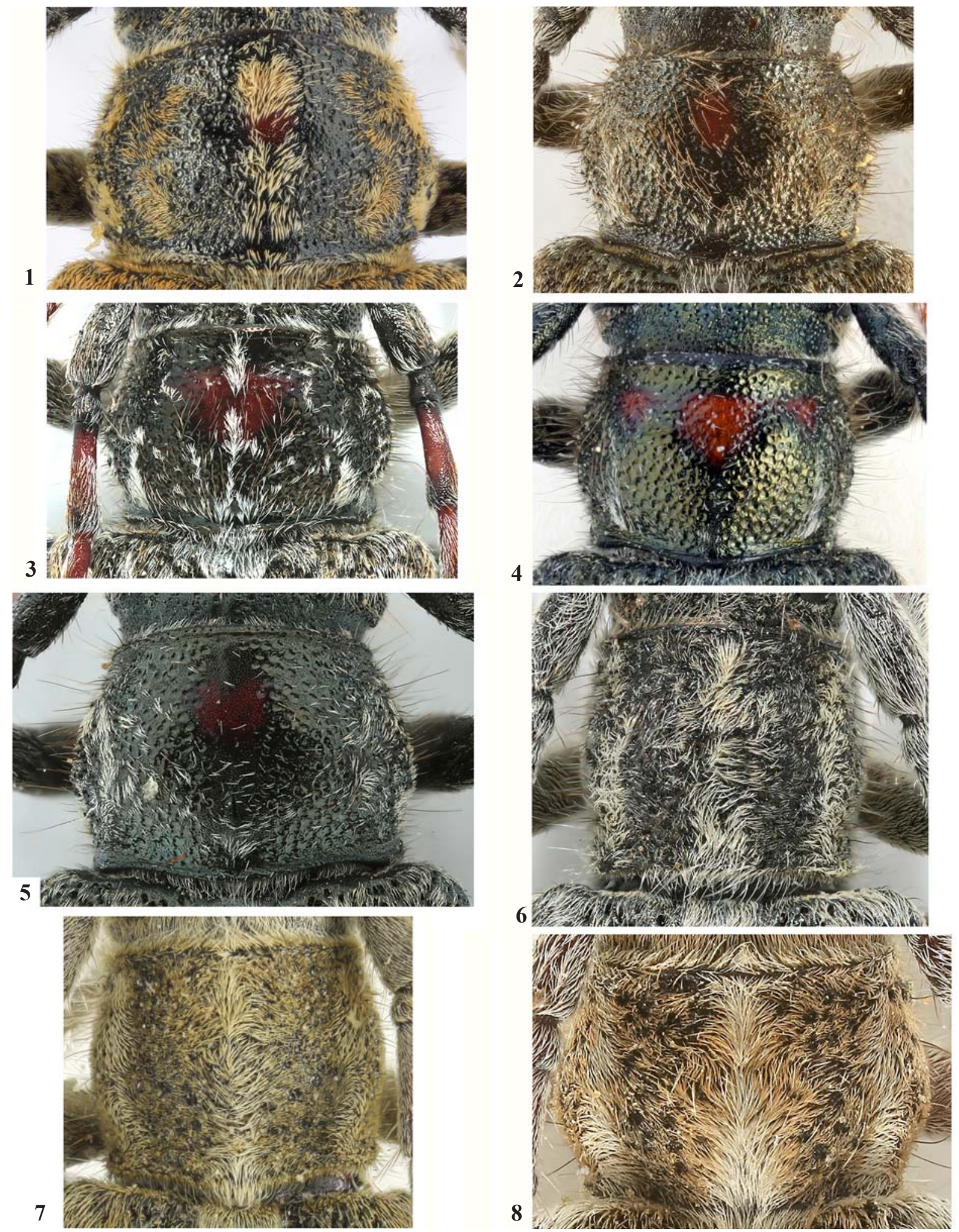

Figs 1-8. Pronotum of Pilemia (1-5) and Pseudopilemia (6-8) subgen.n.: 1 - Phytoecia (P.) annulata Hampe, 1852; $2-P h(P$. breverufonotata Pic, 1952; 3 - Ph. (P.) griseomaculata Pic, 1891; 4 - Ph. (P.) angusterufonotata Pic, 1952; 5 - Ph. (P.) tigrina Muls., 1851; 6 - Ph. (P.) hirsutula (Frölich, 1793); 7 - Ph. (P.) hirsutula homoiesthes Ganglbauer, 1888; 8 - Ph. (P.) konyaensis Danilevsky, 2010; $1-7$ - males, 8 - female.

Рис. 1-8. Переднеспинки Pilemia (1-5) и Pseudopilemia (6-8) subgen.n.: 1 - Phytoecia (P.) annulata Hampe, 1852; 2 - Ph (P.) griseomaculata Pic, 1891; 3 - Ph. (P.) breverufonotata Pic, 1952; 4 - Ph. (P.) angusterufonotata Pic, 1952; 5 - Ph. (P.) tigrina Muls., 1851; 6 - Ph. (P.) hirsutula (Frölich, 1793); 7 - Ph. (P.) hirsutula homoiesthes Ganglbauer, 1888; 8. Ph. (P.) konyaensis Danilevsky, 2010; 1-7 - самцы, 8 - самка. 


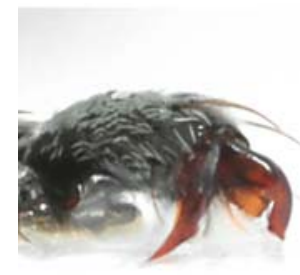

9

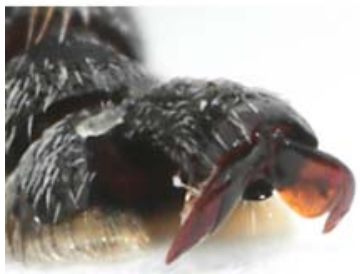

13

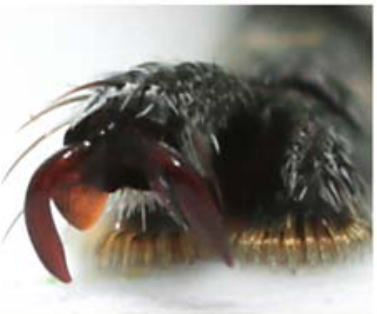

10

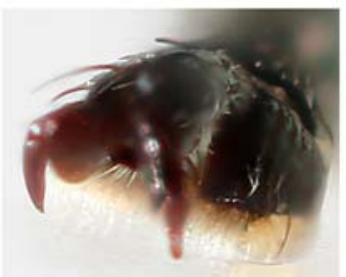

14

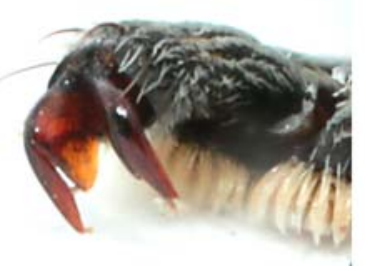

11

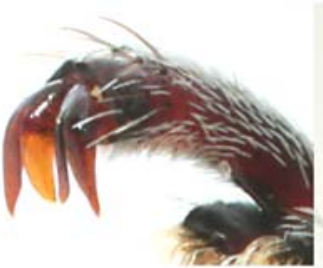

15

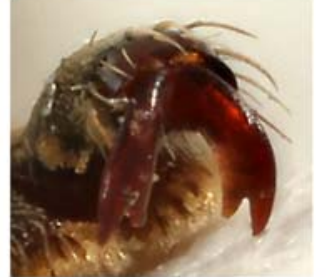

12

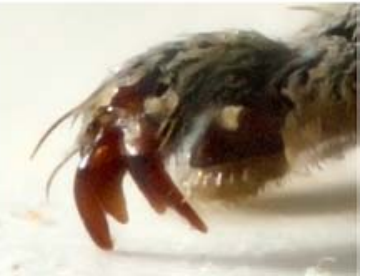

16

Figs 9-16. Claws of Pilemia (9-14) and Pseudopilemia (15-16) subgen.n.: 9 - Ph. (P.) angusterufonotata Pic, 1952; $10-$ Ph. (P.) griseomaculata Pic, 1891; 11 - Ph. (P.) breverufonotata Pic, 1952; 12 - Ph. (P.) annulata Hampe, $1852 ; 13$ - Ph. (P.) tigrina Muls., 1851; 14 - Ph. (P.) serriventris Holzschuh, 1984; 15 - Ph. (P.) hirsutula (Frölich, 1793); 16 - Ph. (P.) konyaensis Danilevsky, 2010.

Рис. 9-16. Коготки Pilemia (9-14) и Pseudopilemia (15-16) subgen.n.: 9 - Ph. (P.) angusterufonotata Pic, 1952; 10 - Ph. (P.) griseomaculata Pic, 1891; $11-P h$. (P.) breverufonotata Pic, 1952; 12 - Ph. (P.) annulata Hampe, $1852 ; 13-$ Ph. (P.) tigrina Muls., 1851; 14 - Ph. (P.) serriventris Holzschuh, 1984; 15 - Ph. (P.) hirsutula (Frölich, 1793); 16 - Ph. (P.) konyaensis Danilevsky, 2010.

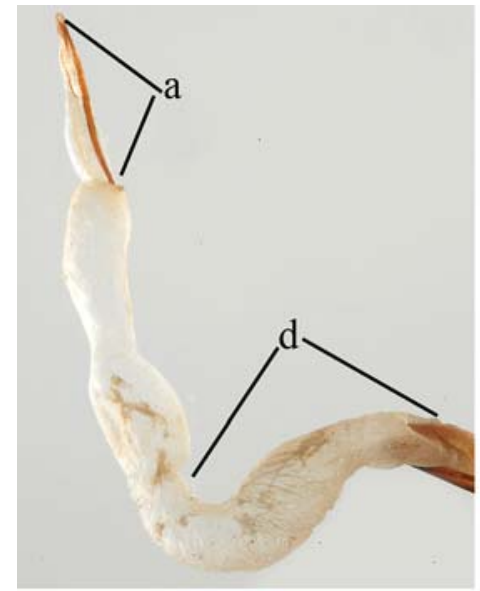

17

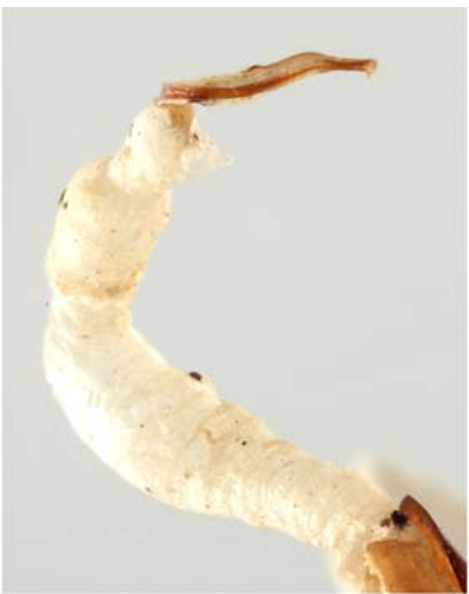

18

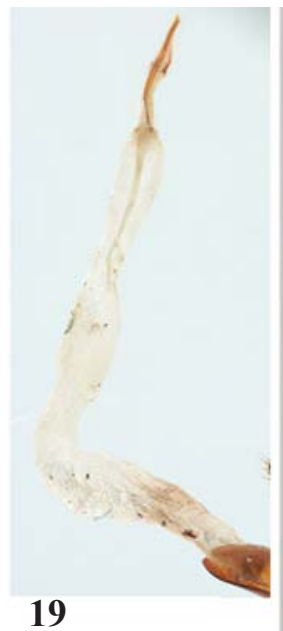

19

Figs 17- 20. Endophallus of Pilemia (17-19) and Pseudopilemia (20) subgen.n., total view: $17-P h$. (P.) griseomaculata Pic, 1891; $18-P h$. (P.) annulata Hampe, 1852; $19-$ Ph (P.) breverufonotata Pic, 1952; 20 - Ph. (P.) hirsutula (Frölich, 1793); $a$ - apical sclerits; $b$ - basi-dorsal crista; $c$ - BLV-sclerits; $d$ - basal phallomer.

Рис. 17-20. Эндофаллус Pilemia (17-19) и Pseudopilemia (20) subgen.n., общий вид: 17 — Ph. $(P$. griseomaculata Pic, 1891; 18 - Ph. (P.) annulata Hampe, 1852; $19-$ Ph (P.) breverufonotata Pic, 1952; 20 - Ph. (P.) hirsutula (Frölich, 1793); $a$ - апикальные склериты; $b$ - базидорсальный гребень; $c-$ BLV-склериты; $d$ - базальный фалломер.

Pygidium in both sexes of Pilemia emarginate apically; abdominal ventrites usually with 1-3 denticles developed in different degree (absent as $P$. angusterufonotata Pic, 1952 and P. smatanai Holz., 2003); inner part of claws wide and short (Figs 9-14), triangular (except of $P$. annulata Hampe, 1852 with the same structure of claws as $P$. hirsutula). Sclerotization of basal phallomer including basidorsal crista absent; central apical sclerite of endophallus twice or more longer than others (Figs 17-19, 21-23). Male antennae reaching apical elytral third or shorter, cuticle of antennomeres bicolour even in darkened specimens; antennomeres in the nominotypical subgenus shorter and more robust than in Pseudopilemia subgen.n.; antennal pubescence distinctly ringed; ventral lobes of eyes twice as long as genae; male pronotum distinctly transverse (Figs 1-5), barrel-shaped, with red spot on disc (in P.annulata sometimes almost reduced or hidden under pubescence); cuticle of body distinctly shiny, usually with metallic shade. Elytral pubescence distinctly patterned; thick setae short and recumbent, weakly visible; elytra usually emarginate apically. 

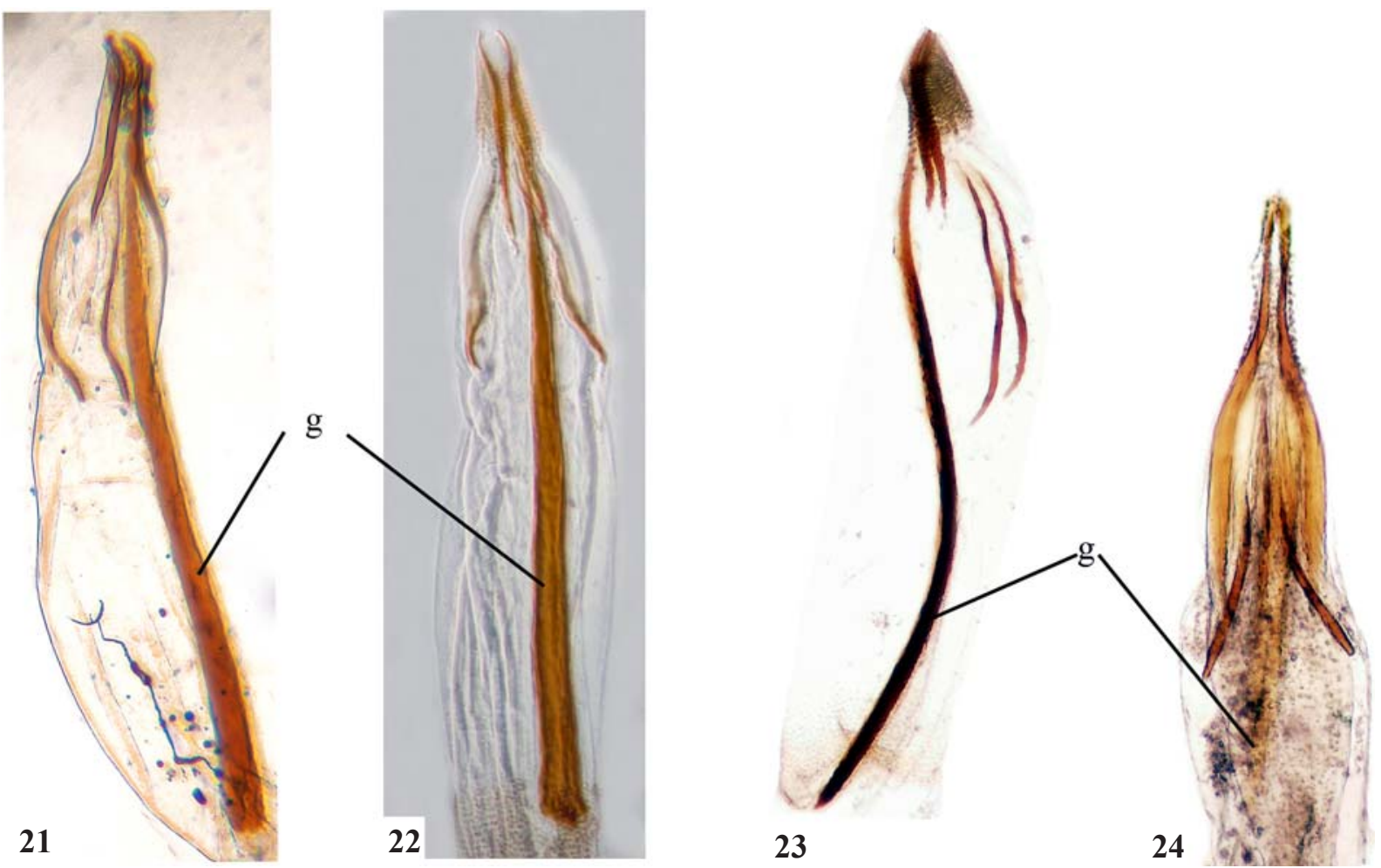

Figs. 21-24. Apical endophallic sclerits of Pilemia (21-23) and Pseudopilemia (24) subgen.n.: 21 - Ph. (P.) griseomaculata Pic, 1891; 22 - Ph. (P.) tigrina Muls., 1851; 23 - Ph. (P.) breverufonotata Pic, 1952; 24 - Ph. (P.) hirsutula (Frölich, 1793); $g$ - central apical sclerite.

Рис. 21-24. Апикальные склериты эндофаллуса Pilemia (21-23) и Pseudopilemia (24) subgen.n.: 21 - Ph. (P.) griseomaculata Pic, 1891; 22 - Ph. (P.) tigrina Muls., 1851; 23 - Ph. (P.) breverufonotata Pic, 1952; 24 - Ph. (P.) hirsutula (Frölich, 1793); $g$ - центральный апикальный склерит.

COMPOSITION. The typical species of the new subgenus are Ph. (P.) evae D.Marklund et S.Marklund, 2014, $P h$. (P.) kruszelnickii Szczepański et Karpiński, 2017, Ph. (P.) konyaensis Danilevsky, 2010. Studied by me serial material (3 males and 6 females) from the type locality does not support characters used in the description of $P h$. $(P$.) buglani$\mathrm{ca}$ D.Marklund et S.Marklund, 2014. Noted by the absence erect setae on the pronotum, the bald outer edge of anterior tibia result from the worn out single specimen that used to describe. Thus, Ph. (P.) buglanica D.Marklund et S.Marklund, $2014=$ Phytoecia $(P$.$) hirsutula (Frölich, 1793) syn.n. The$ specimens of the Ph. (P.) vagecarinata Pic, 1952 are unknown for me, the holotype depository is also unknown [Özdikmen, Turgut, 2010]. Beetles in the photoreport after an expedition to Syria [http://buprestidae.blogspot.com/2006/ $11 /$ syria-2005.html] is Ph. hirsutula in my opinion. The subgeneric position of $P h$. $(P$.) vagecarinata is difficult to understand according to the description, especially based on simple (!) claws. Some characters, such as large lower lobes of eyes and white spots on elytra, suggest that this species may be close to Pilemia. Withal, M. Pic also was not sure in the correct position of this species in the subgenus Pilemia [Pic, 1952: 3] and compared it also with Pseudocoptosia Pic, 1900 .

ACKNOWLEDGEMENTS. The author cordially thank colleagues who provided the material for study: Dr. A.A. Gusakov (Moscow, Russia), Dr. A.I. Miroshnikov (Krasnodar, Russia), Dr. H. Schilhammer (Vienna, Austria), Dr.
S.Blank (Muncheberg, Germany), Dr. J.Frisch (Berlin, Germany), Dr. M.Balke (Munich, Germany), Dr. J.Hajek (Prague, Czech Republic).

\section{References}

Daniel K. 1906. Revision der Phythoecia-Untergattung Pilemia Fairm. // Münchener Koleopterologische Zeitschrift. Bd.3. S.55-64.

Danilevsky M. 2016. http://cerambycidae.net/catalog.pdf

Kasatkin D.G. 2006. [The internal sac of aedeagus of longhorned beetles (Coleoptera: Cerambycidae): morphology, nomenclature of structures, taxonomic significance] // Caucasian Entomological Bulletin. Vol.2. No.1. P.83-10 [in Russian].

Löbl I., Smetana A. (eds.). 2010. Catalogue of Palaearctic Coleoptera. Vol.6. Chrysomeloidea. Stenstrup: Apollo Books. 924 p.

Marklund D., Marklund S. 2015. Description of two new species of Phytoecia (Pilemia) Fairmaire, 1864 from Eastern Turkey (Coleoptera, Cerambycidae, Phytoeciini) // Lambillionea. Vol.114. No.3. P.274-277. 3 figs.

Szczepański W.T., Karpiński L. 2017. A new species of the genus Phytoecia Dejean, 1835 (Coleoptera: Cerambycidae) from Greece // Zootaxa. Vol.4268. No.1. P.141-146.

Özdikmen H., Turgut S., 2010. An overview on the palaearctic subgenus Phytoecia (Pilemia) Fairmaire, 1864, with a new species Phytoecia (Pilemia) samii sp. n. from Turkey (Coleoptera: Cerambycidae: Lamiinae) // Munis Entomology \& Zoology. Vol.5. No.1. P.90-108. 12 Figs.

Pic M. 1952. Contribution à l'étude des Pilemia Frm. [Longicornes] // Diversites Entomologiques. No.11. P.1-3. 